\title{
Albanian Universities and e - Learning
}

\author{
Luan Bekteshi, PhD Cand. \\ Faculty of Economy \\ University of Elbasan "A. Xhuvani" \\ luanbekteshi@yahoo.com
}

\begin{abstract}
Today's society is undergoing great transformations in every sector. One of the most important transformations of the social life is the making of technology and internet available to masses. The technology and internet have also visibly transformed the education sector. The society is facing continuous challenges related to the competition, globalisation and the demand from the job market for qualified employees. These challenges go by side by side with the transformation of the education sector, where a great deal is being invested on the use of ICT, mass education, and the introduction of new methods and tools of teaching. The use of ICT and e-Learning is an important challenge faced by Albanian universities in the mission to improve the quality of teaching, students' results, and mass education, and achieve the necessary standards. Priorities like equal access to education and lifelong learning would be only slogans without the use of ICT and e-Learning. Polls and interviews were conducted for this study, to obtain a view of the use of e-Learning and the approach to e-Learning in Albanian universities, and also of the government and universities policies. Conclusions of this study are obtained by processing data from questionnaires filled by lecturers in some of the main Albanian universities.
\end{abstract}

Keywords: Information and Communication Technology, e-learning, lifelong learning, education, university, information.

\section{Introduction}

There were only 14000 university students in Albania up until 1990, and capacities were limited. University admissions were limited and controlled, and not all youth who wanted to attend higher education were accepted.

The political changes after the 1990 also brought important quantitative and qualitative transformation for the Albanian universities, such as the increase in capacities and admissions, and the opening of new universities.

The biggest quantitative changes happened in 2005, when admission capacities went up to 52000 and 175000 in 2014. This period also saw some qualitative changes, the most important of them being the participation of Albania in the Bologna Process in 2003, which was accompanied by the restructuring and upgrading of cycles and content of the study programmes, adaptation of the higher education curricula to the Bologna system, and the concept of ECTS (European Credits Transfer System).

The private sector brought a good managerial experience in the sector of higher education after the year 2000 , which had its effect in the public higher education as well.

There were 59 institutions of higher education in Albanian in 2014, of which 15 were public and 44 private. The total number higher education students were 175000 , from whom 142000 attended public universities. 


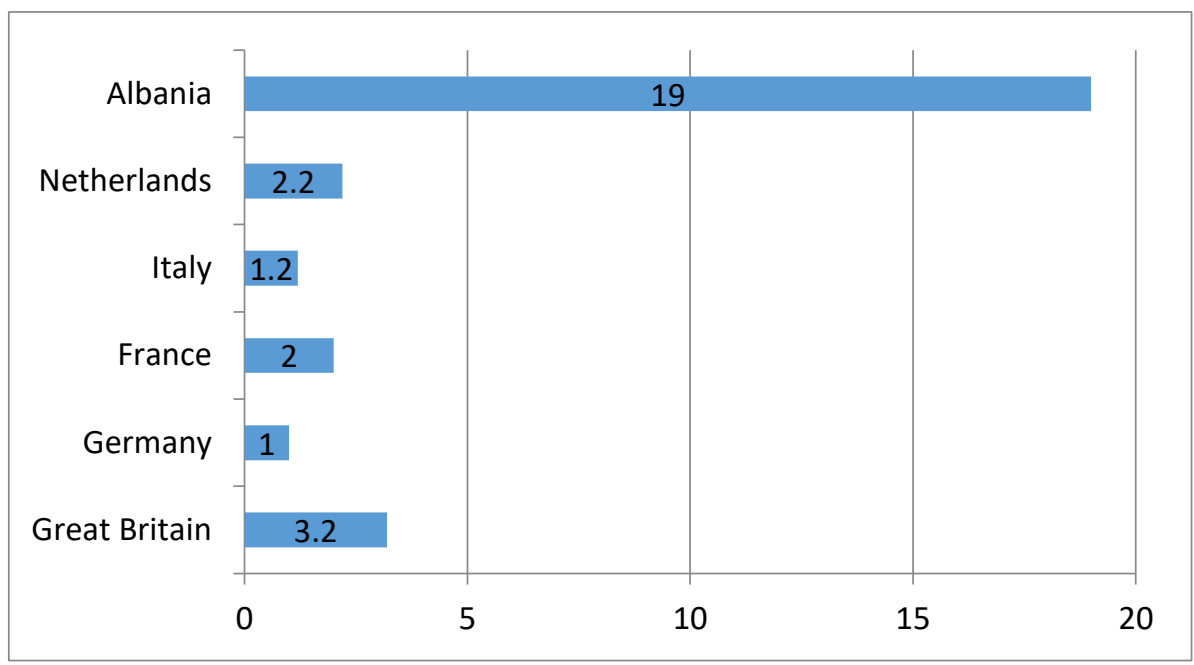

Number of universities / million inhabitants, according to the report of Ministry of Education and Sports of Albania

For a country like Albania, with 2894475 residents and with only $0.4-0.6 \%$ of the GDP being invested on the higher education, this number is too higher even compared to developed countries with long tradition in education.

Education in Albania is considered an important means of life improvement for the population and of economic growth for the country.

Part of the strategies of the Albanian government for the higher education are the strategies for the development and mass use of ICT and e-Learning as very important means of support to the teaching and learning process in universities.

That said, the need for the mass use of ICT in the Albanian universities is immediate, and the following are stimulating factors:

- The education policies in Albania which emphasise the increasingly important role of education in the process of the economic growth of the country, reduction of the poverty, and preparing a workforce able to adapt to the new conditions of the global competitive economy.

- $\quad$ The growing competition in education, with private universities now operating in the sector. The assessment criterion of a university is its competitiveness towards the other universities, for which the assessing or leading boards should obtain academic, pedagogic and administrative information.

- The increase of the number of higher education students, which is accompanied by an increase in the data that universities administer. The ever increasing amount or numbers of the following elements data and information, the complexity of the problems accompanying the higher education and the number of students and lecturers - require the use of an information system for their full management. This will increase the quality of administrative and academic processes will make possible equal access to information and procedures, will improve and strengthen the quality of university management, and will increase the use of technology in education and science.

- The increase of transparency of actions related to the administration of data on students, academic staff, lecture times, literature, taxes and financial obligations of the students, etc.

- $\quad$ The increase of teaching and reading quality.

- Improvement of student administration quality - from the moment they enrol at university, attendance of academic programmes, gradual assessment, up to the completion of their academic programmes.

- The reduction of administration costs: the Information System has the potential to ease the administrative procedures and bring transparency on economic-financial transactions. The system 
makes possible for the leading education institutions (Ministry of Education) or other institutions to monitor the procedures in universities and obtain correct information, which positively affects the prestige of the university. This transparency is also valuable to the society and the university community.

- Improvement of university management: the information system requires a computerised process. Such a system helps university directors in decision making and increases their credibility.

- Having all the data in one central database.

- Easier decentralisations of operations into separate departments.

- Automatization of the operational processes concerning HR management.

- Implementation of best practices related to main processes of the university (self-service).

- The understanding and easy use of the information system by the users: students, lecturers and administration staff.

Many public and private universities in Albania consider the e-Learning platform as an indispensable addition to theirnormal infrastructure. This is something normal for universities of many countries that have built specific strategies in order to expand the range of services offered through the use of technology.

E-Learning is being used by Albanian universities as an indispensable factor characterised by the elimination of the time and geographic barriers between students and lecturers, increases the interaction between them, and affects the quality of teaching and learning process in universities.

The ICT has been included in curricula in Albania, accompanied by the preparation of the necessary human capital to use it, thus increasing the possibilities to read and increase the quality of education. Initiatives coming by both the government and universities consist in information services, professors' capacity building, infrastructure, content development and organizational structures.

\section{LITERATURE REVIEW}

Previous societies were characterised by an education system where teachers and students physically interact in the classroom. The view on education during the last decades has changed because society has been characterised by the technological developments and the massive use of internet. (Castells, 2001).

Duderstat (1999) agreed that the use of ICT in education and suggested that institutions of education have undergone changes and will continue to be changed by the ICT.

These changes are:

- In the methods of education: ICT has changed the way information is read and learnt. It offers the possibility for synchronised reading, when students read the same material in different time and places. ICT has also brought new ways of teaching.

- In the scope of education: Education has been viewed as only teaching and reading. Through the use of ICT it is now seen as a process of creating, storing, integrating, transmitting and implementing knowledge.

One of the forms of technology that improve the learning process is e-Learning. Different authors give different definitions of e-Learning. One of the definitions is: "e-Learning system is a complete technological, organisational and administrative process, which serves students as a helping tool in the process of learning through internet. ". (Levy \& Murphy, 2002).

Piskurich (2003) defines e-Learning as "Learning that uses computers networks or the web as a delivery or mediation mechanism".

Sheperd (2003) definition: "e-Learning uses computers and computer networks as an additional and supplemental channel of communication, which connects readers with reading outlets, other people (fellow learners, sources, facilitators), data (on learning, media, people), and with processing skills.

According to Laurillard (2004), e-learning describes the interaction in which students use different types of ICTs in their learning process. 
But, on the other hand, implementing e-learning in teaching involves a variety of restructuring that must be performed in educational activities. Moving from a traditional learning environment to an e-learning environment means a change in teachers and students roles (Cohen \& Nycz, 2006).

In order to apply e-Learning in teaching and learning a university must either have the suitable infrastructure, or invest in creating this technological infrastructure and of the sources needed for the application of e-Learning.

For example, Gulati (2008) explained that the lack of different types of resources is a common problem in the take-up of elearning.

This demands significant investments by the universities and in the case of public universities the intervention of the government is needed to finance for the necessary sources and infrastructure.

Governments of different countries have allocate considerable funds during the last decades towards a higher efficiency and market competitiveness, and towards a better teaching and learning process.

Private investors and different foundations have followed the same strategy to achieve these improvements in the private education system, where a great deal is being invested on the use of Information Systems. According to the statistics from the Ministry of Education and Sport in Albania, public and private universities in 2014 have invested 37\% more on the use of ICT in the teaching and learning process and on the improvement of administration processes of the universities.

Many studies have concluded that the implementation of e-Learning has resulted in the transformation of the teaching and learning ways and in students achieving results.

Hawkes and Cambre (2000) claim that in order to achieve results, students must take responsibility for their own learning.

According to Ellis and Allen (2004), e-learning covers a wide set of applications and processes, such as Web-based learning, virtual classrooms, and digital collaboration. It includes the delivery of content via Internet, intranet/extranet (LAN/WAN), audio-and videotape, satellite broadcast, interactive TV and CD-ROM.

According to Putzhuber (2003), nowadays e-learning refers to learning that is delivered or enabled via electronic technology. It encompasses learning delivered via a range of technologies such as the internet, television, videotape, and computer-based training. In principle, e-learning is a kind of distance learning. Learning materials can be accessed from the web or intranet via computer and tutors and learners can communicate with each other using e-mail, chat or discussion forums. Therefore, it can be used as the main method of delivery of training or as a combined approach with classroombased training.

Oliver (2001) has identified some of the problems encountered in the successful application and continuous use of eLearning in the higher education in Australia. Factors that support and improve the quality of e-Learning are:

- Expertise of the lecturers in online teaching

- Online Teaching

- Use of technology in teaching

- Training of lecturers

- $\quad$ Readiness of students to work online

- Technological skills

- Access to technology

- Reading of technology

- Infrastructure of technology

- Hardware and software

- Offers of services

- Distribution of reading sources and content

- Re-usable reading objects

Watkins and Corry, 2004 determine the success of e-learning as a combination of two factors as in the figure below: 


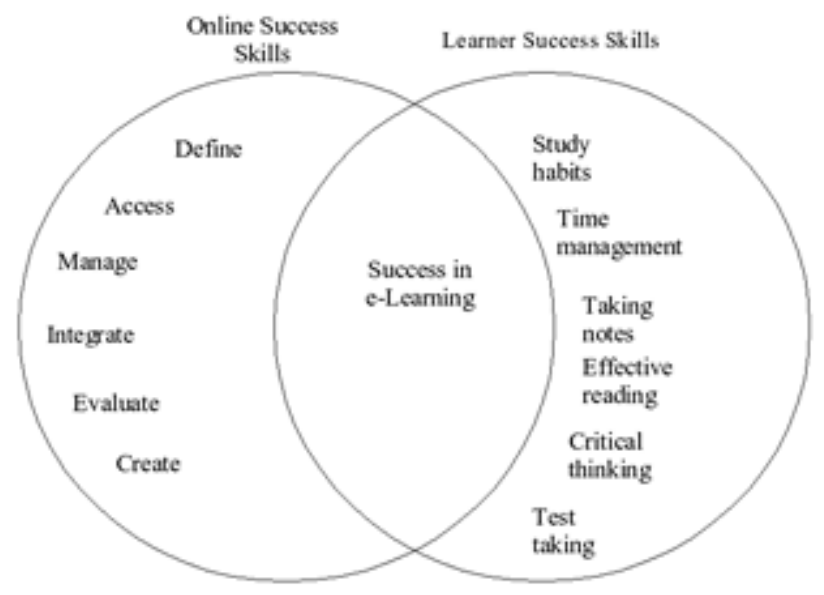

\section{METHOD}

90 questionnaires were given to lecturers for the scope of this study as below, although not all of them filled the questionnaire:

- 25 lecturers of the university of Elbasan

- 20 lecturers of the university of Tirana

- 18 lecturers of the agricultural university

- 12 lecturers of the university of Korça

- 10 lecturers of the university of Gjirokastra

- 5 lecturers of the university of Durres

Participants were asked questions related to:

- Their years in teaching

- Faculty where the teach

- $\quad$ Subject they teach

- How they assess their individual skills of ICT use in teaching and learning

- Their individual opinion on e-Learning

- How they conduct lectures, seminars and tests

- Three factors of e-Learning affecting positively and three factors of e-Learning affecting negatively the teaching and learning process

- Readiness of students to work online

- Level of ICT implementation in universities

- Access in the technological infrastructure 
- Access in the online information sources

- Course content towards the related literature

- If content of courses is updated in accordance with the curriculum

- If browsing and discussions in forums and online chats help

- Individual opinions on e-Learning (the technology aspect, content, access etc)

\section{Results}

Data from the questionnaires were used to assess the level of e-Learning in the Albanian universities, the obstacles it encounters, and to obtain recommendations for the normal use e-Learning in the university environment.

- 72 of the 85 lecturers that filled the questionnaires confirm that e-Learning is an important helping tool in improving the quality of teaching and learning, the students' knowledge, and the student-lecturer interaction.

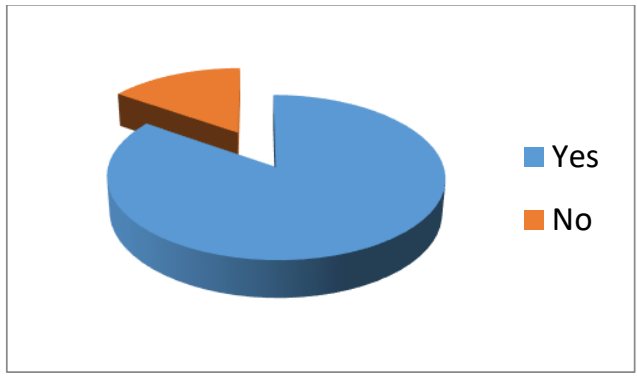

\section{Evaluation of e-learning}

The answers received did not suggest any relation between what they teach and their opinion on e-Learning, but there is a relation between their opinion on e-Learning and their years of experience in the job. Four lecturers who lacked ICT skills accepted they were sceptical on the role of ICT in their teaching.

- 51 of the 85 lecturers that filled the questionnaires confirm that ICT and e-Learning are not being implemented in the right level.

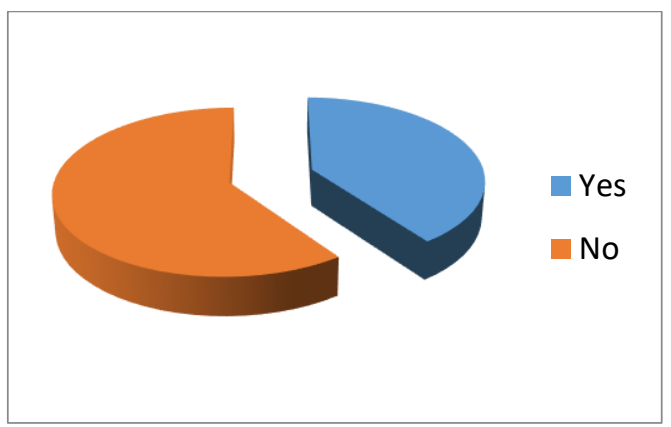

Appropriate level

- 72 lecturers confirm they have good working knowledge of ICT and when possible they give online assignments to students, assess online, and make use of online literature which they also recommend to students. 
- $\quad$ Almost all lecturers see e-Learning as the near future of the universities in order to cope with social challenges. They also encourage students to have a more conscious and positive attitude on the use of e-Learning in their studies.

- Almost all lecturers have a positive view on the possibility to apply e-Learning, online content, and the wide range of literature they and the students need for their continuous preparation.

- According to the answers from the lecturers, the most often positively affected factors are:

\begin{tabular}{|l|l|}
\hline ANSWER & No. of answers \\
\hline Interaction & 47 \\
\hline Increase of the level of students' preparation & 31 \\
\hline Reduction of time and financing needed to find the necessary literature & 27 \\
\hline Supporting the administration of the academic activity & 15 \\
\hline
\end{tabular}

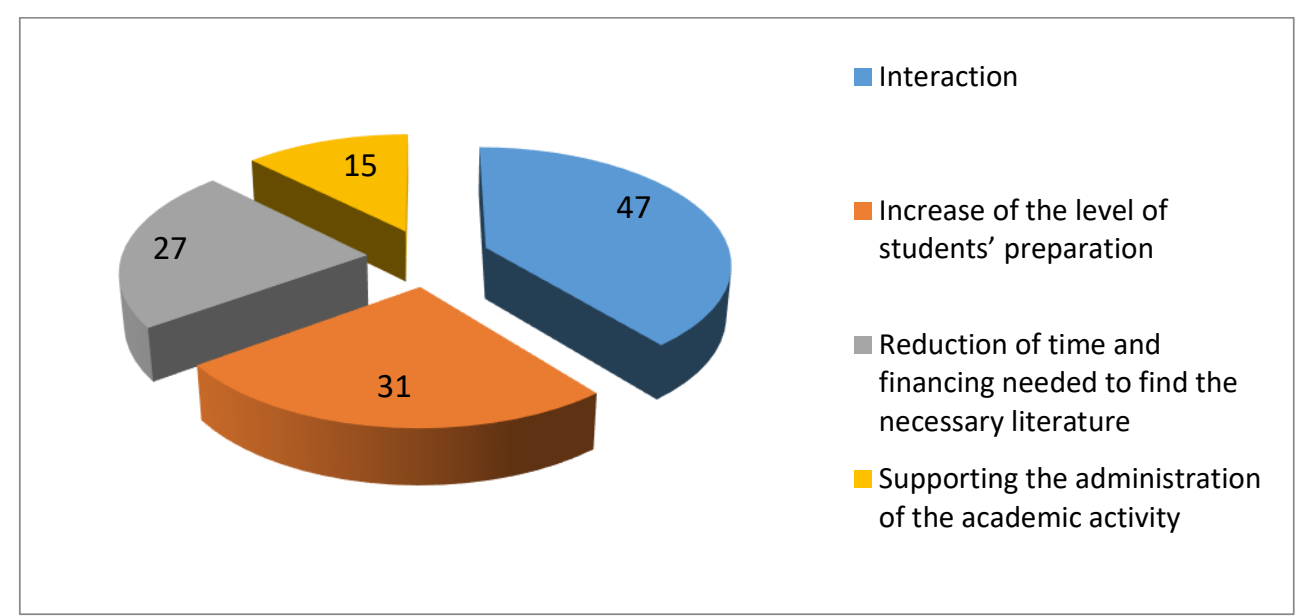

- Obstacles that have a negative effect, according to the number of answers

\begin{tabular}{|l|l|}
\hline ANSWER & No. of answers \\
\hline Lack of funds & 67 \\
\hline Lack of materials & 52 \\
\hline Readiness of universities & 26 \\
\hline Laws and government strategies & 22 \\
\hline Lack of permanent personnel & 16 \\
\hline
\end{tabular}




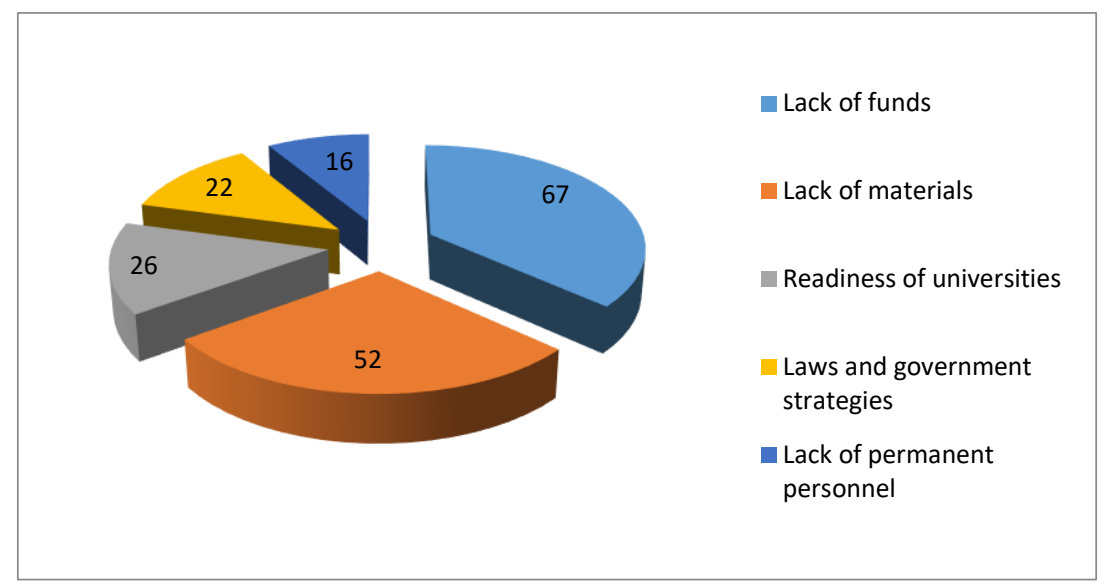

- 81 lecturers confirm they are ready to work online. The rest - 4 lecturers - cannot work online because they do not have enough knowledge on the use of ICT. These four lecturers also confirm that they full follow the traditional methodology of teaching in the university.

- Lecturers confirm that investments in ICT and e-Learning are far behind what is invested in universities of other European countries, and this penalises students, lecturers and the quality of teaching and preparation in the universities.

\section{Conclusions and recommendations}

Data from the questionnaires mirror the implementation of e-Learning in universities.

Although Albanian universities are investing towards the use of ICT in education, the level of ICT use is lower compared to countries of EU of which Albanian aspires to become a member. Only a small number of universities, mainly private, have managed to use ICT as a tool to reorganise study programmes, content, curricula etc.

Because finances of universities are limited, the Ministry of Education and Sport must support its strategies for the public universities with the relevant funds and monitor the implementation of these strategies. The dissatisfaction of students and their parents with the public universities makes many of them enrol to private universities although it costs them more.

Reforms are needed in the education system in order to give ICT and e-Learning the deserved role as two of the best ways to provide better studying opportunities for students, and increase the quality of their formation to make them capable of meeting the requirements of the national and global job markets. The government must work with internet providers in order to offer this service at lower prices, and build strategies for the computerisation of the universities. The latest project - "I Learn" - of the Ministry of Education and Sport with the cooperation of the Ministry of Innovation and Public Administration is a positive effort towards that aim. With education being one of the priorities of the government, e-Learning must become an important element of the National Strategy for ICT.

The Albanian universities must also develop their own strategies to help and facilitate the implementation of e-Learning as a means that assists students to access the most needed information, enable them to solve problems, and have the opportunity of the continuous learning after completion of academic studies.

Universities must offer training in order to qualify personnel who will support students and lecturers in e-Learning. 


\section{ACKNOWLEDGEMENT}

I would like to thank the participants in the study who answered the questions. Their answers helped in creating a fuller picture of e-Learning in some public universities in Albanian, and their opinions are useful in the improvement of the eLearning situation in these universities.

\section{REFERENCES}

[1] Castells, M. (2001), The Internet Galaxy: Reflections on the Internet, Business and Society. Oxford: Oxford University Press

[2] Duderstat, J.J (1999) "Can Colleges and Universities Survive in the Information Age?" in R. N. Katz (Ed), Dancing with the Devil: Information Technology and the New Competition in Higher Education, San Francisco: Jossey-Bass Publishers.

[3] Eli, B. Cohen \&MalgorzataNucz (2006) "Learning Objects and E-Learning: an Informing Science Perspective" ,Interdisciplinary Journal of Knowledge and Learning Objects Volume 2, Editor: Alex

[4] Ellis, R. and Allen, M. (2004), Down with boring E-Learning - Interview with e-learning guru Michael Allen, Retrieved from http://www.astd.org/LC/2004/0704_allen.htm

[5] Gulati, S. (2008), Technology-enhanced learning in developing nations: A review, International Review of Research in Open and Distance Learning

[6] Hawkes, M. and Cambre, M, (2000). The Cost Factor: When is Interactive Distance Education Justifiable?, Technology Horizons in Education Journal, 28(1)

[7] Koohang, A. and Harman, K. (2005). Open Source: A metaphor for e-learning. Informing Science: The International Journal of an Emerging Trans discipline, 8, available athttp://inforum.nu/Articles/Vol8/Kooh.pdf

[8] Laurillard, D. (2004). The next level in e-learning, Proceedings of Online Education Berlin, (Berlin, ICWE)

[9] Levy, Y. and Murphy, K. E. (2002).Toward a value framework for online learning systems. Proceedings of the $35^{\text {th }}$ Hawaii International Conference on System Sciences (HICSS-35),Big Island, Hawaii

[10] Levy, Y. (2006).Assessing the value of e-learning systems. New Jersey: John Wiley \& Sons Inc.

[11] Mayes, T and De Freitas, S. (2004), Review of e-learning theories, frameworks and models. JISC e-Learning Models Desk Study, Issue 1

[12] Oliver R. (2001), "Assuring the quality of online Learning in Australian Higher Education" paper presented at the Moving Online Conference II, Goldcoast, Australia available at: http://elrond.scam.ecu.edu.au/oliver/2001/mocpaper.pdf

[13] Piskurich George M. (2003), The AMA Handbook of E-Learning: Effective Design, Implementation and Technology Solution. New York, USA: AMACOM

[14] Putzhuber, W. (2003), From E-Learning to Knowledge Management- Bringing the Gap, Institute for Information Processing and Computer Supported New Media

[15] Rosenberg, M. J. (2001), E-Learning: Strategies for Building Online Learning in the Digital Age. New York: McGraw-Hill

[16] Shepherd, C. (2003).E-learning's greatest hits. Brighton, UK: Above and Beyond.

[17] Watkins, R. and Corry, M. (2007), E-Learning Companion: A Student's Guide to Online Success, 2/E Houghton Mifflin Company

[18] Wiley, D. A. and Waters, S. H. (2005), Scoping and Sequencing Educational Resources and Speech Acts: A unified design framework for learning objects and educational discourse. Interdisciplinary Journal of Knowledge and Learning Objects, 1, Available at http://ijklo.org/Volume1/Wiley.pdf

[19] Ministry of Education and Sport: 2014, Final report," Reform of Higher Education and Research" available at http://www.arsimi.gov.al/files/userfiles/reformaalksh/Raport_Final_Ministria_Arsimit.pdf

[20] OECD, (2005). E-Learning in tertiary Education: Where do we stand? Education \& Skills, Vol 4

[21] AKEP, (2015). Annual Report 2014, available at http://www.akep.al/en/publications/annualreports/annual\%report2014.pdf

[22] INSTAT, (2015), Population in Albania 1 January 2001-2014, available at http://www.instat.gov.al/en/themes/population.aspx 